JPPKMI 1 (1) (2020)
JURNAL PENELITIAN DAN PENGEMBANGAN
KESEHATAN MASYARAKAT INDONESIA
Jttps://journal.unnes.ac.id/sju/index.php/jppkmi

\title{
Pemberian Asi Ekslusif Dapat Menurunkan Risiko Obesitas pada Anak Balita
}

\author{
Lea Morry Br Ginting ${ }^{1} \bowtie$, Besral $^{1}$
}

${ }^{1}$ Fakultas Kesehatan Masyarakat, Univesitas Indonesia, Indoneisa

\begin{tabular}{l}
\hline Info Artikel \\
\hline Sejarah Artikel: \\
Diterima Mei 2020 \\
Disetujui Juni 2020 \\
Dipublikasikan Juli 2020 \\
\hline Keywords: \\
Exclusive Breastfeeding, \\
Obesity, Children \\
\hline URL: \\
$\underline{\text { https://iournal.unnes.ac.i }}$ \\
$\underline{\text { d/siu/index.php/ippkmi }}$ \\
$\underline{\text { Larticle/view/41421/173 }}$ \\
$\underline{42}$ \\
\hline
\end{tabular}

\begin{abstract}
Abstrak
Pendahuluan: Pemberian ASI eksklusif adalah Bayi hanya diberi ASI saja, tanpa tambahan cairan lain seperti susu formula, air jeruk, madu, air teh, air putih dan tanpa tambahan makanan padat seperti pisang, pepaya, bubur susu, biskuit, bubur nasi dan tim, selama 6 bulan. ASI mengandung hormon dan faktor pertumbuhan yang ideal. Berbeda dengan kandungan susu formula yang memerlukan pengenceran dengan kadar tertentu yang berbeda-beda untuk setiap anak. Jika pengenceran terlalu pekat, dapat memicu kegemukan dan obesitas. Bayi yang mendapat ASI pada umumnya lebih ideal daripada bayi yang mendapat susu formula. Manfaat ASI bagi bayi dalam jangka panjang adalah dapat mengurangi risiko terjadninya obesitas. Tujuan penelitian ini adalah untuk menilai hubungan antara pemberian ASI ekslusif dengan risiko obesitas pada anak. Metode: Metode penelitian ini adalah telaah jurnal. Hasil: Hasil telaah dari 8 jurnal yang memenuhi kriteria adalah terdapat 5 jurnal yang menyatakan pemberian ASI eksklusif menurunkan risiko obesitas. Penutup: Disarankan agar promosi dan praktik pemberian ASI eksklusif lebih diintensifkan, terutama untuk mencegah risiko obesitas pada anak.
\end{abstract}

\begin{abstract}
Introduction: Exclusive breastfeeding is infants only breast-fed, without the addition of other liquids such as formula milk, orange juice, honey, tea water, water and without the addition of solid foods such as bananas, papaya, milk porridge, biscuits, rice porridge and team, for 6 months. Breast milk contains ideal hormones and growth factors. In contrast to the content of formula milk that requires dilution with different levels for each child. If the dilution is too concentrated, it can trigger obesity and obesity. Babies who get breast milk are generally more ideal than infants who get formula milk. The benefits of breast milk for babies in the long term is that it can reduce the risk of obesity. The purpose of this study was to assess the relationship between exclusive breastfeeding and the risk of obesity in children. Methods: This research method is a journal study. Results: The results of the study of 8 journals that met the criteria were 5 journals that stated exclusive breastfeeding lowered the risk of obesity. Closing: It is recommended that the promotion and practice of exclusive breastfeeding be intensified, especially to prevent the risk of obesity in children.
\end{abstract}

(C) 2020 Universitas Negeri Semarang

Alamat korespondensi:

Gedung A, Lt.2, Kampus FKM UI Depok

E-mail: besral@ui.ac.id, leamorrvg@gmail.com 


\section{PENDAHULUAN}

Obesitas merupakan masalah kesehatan yang terdapat bukan hanya di negara berkembang tetapi di negara maju. Obesitas disebabkan oleh ketidakseimbangan antara jumlah energi yang masuk dengan yang dibutuhkan oleh tubuh atau ketidakseimbangan dari energy yang masuk dengan yang dikeluarkan (lebih banyak energy yang masuk). Menurut Depkes (2009) Obesitas adalah penyakit kelebihan berat badan minimal 75 persen dari berat ideal. Kondisi ini disebabkan oleh banyak faktor, namun penyebab utamanya adalah konsumsi makanan yang berlebihan, tanpa diimbangi aktivitas fisik dan olahraga. Konsumsi makanan yang berlebihan menyumbangkan banyak sekali energy (yang tidak berguna) ke dalam tubuh. Penyebab lainnya adalah faktor genetik, lingkungan, dan psikis.

Indeks Masa Tubuh (IMT) abnormal pada anak-anak ditentukan oleh persentil usia dan gender berdasarkan grafik pertumbuhan, sebagai jumlah lemak tubuh berubah seiring bertambahnya usia dan berbeda antara anak laki-laki dan perempuan. Pada usia 0-20 tahun, obesitas ditentukan dengan memplot IMT menggunakan grafik indeks-massa-tubuh CC 2000, yaitu diatas persentil $95^{\text {th }}$. Sedangkan pada usia lebih dari 20 tahun, menurut kriteria WHO untuk kawasan Asia Pasifik, obesitas ditentukan jika IMT $\geq 25$. Faktor yang mengakibatkan obesitas pada anak yaitu ibu merokok, berat badan lahir tinggi, pertambahan berat badan bayi cepat, konsumsi minuman manis, fisik tidak aktif, perilaku menetap dan kurang tidur. Selain itu, ada beberapa faktor yang terbukti melindungi anak dan remaja yang kelebihan berat badan dan obesitas, seperti memberikan ASI Eksklusif, konsumsi sarapan pagi dan aktivitas fisik (Ontario Agency for Health Protection and Promotion, 2013).

Obesitas pada masa anak dapat meningkatkan kejadian diabetes mellitus (DM) tipe 2. Selain itu, juga berisiko untuk menjadi obesitas pada saat dewasa dan berpotensi mengakibatkan gangguan metabolisme glukosa dan penyakit degeneratif seperti penyakit jantung, penyumbatan pembuluh darah dan lain-lain. Selain itu, obesitas pada anak usia 6-7 tahun juga dapat menurunkan tingkat kecerdasan karena aktivitas dan kreativitas anak menjadi menurun dan cenderung malas akibat kelebihan berat badan (Sjarif, 2004). Obesitas pada anak berisiko 1,8 kali menjadi obesitas pada masa dewasa. Obesitas pada anak berdampak pada penurunan prestasi belajar dan dampak psikososial seperti kurang percaya diri dan menarik diri dari sosial. Terdapat beberapa faktor yang berperan terhadap kejadian obesitas pada anak. Faktor tersebut antara lain keturunan/genetik; asupan makanan; aktifitas fisik; riwayat makan seperti pemberian ASI, berat badan lahir dan parental obesity. Meningkatnya prevalensi obesitas pada anakanak merupakan tantangan kesehatan masyarakat yang utama di negara maju dan berkembang dengan meningkatkan beban penyakit kronis yang tidak menular. Mencegah obesitas pada masa kanak-kanak adalah sangat penting dalam mengendalikan epidemi obesitas. Pencegah strategi harus dimulai sejak awal kehidupan, karena obesitas sulit diobati pada semua umur, dan obesitas cenderung bertahan hingga dewasa. Menyusui telah terbukti berhubungan dengan insiden obesitas yang lebih rendah di masa kecil. Namun, datanya tidak konsisten, dengan penelitian lain tidak menunjukkan efek yang jelas. Promosi menyusui masih disarankan berdasarkan manfaat kesehatan lainnya (Depleweski, 2018).

Berdasarkan laporan gizi global atau Global Nutrition Report (2014), Indonesia termasuk ke dalam 17 negara yang memiliki 3 permasalahan gizi sekaligus, yaitu stunting (pendek), wasting (kurus), dan juga overweight (obesitas). Hasil Riset Kesehatan Dasar (Riskesdas) tahun 2013 menyebutkan bahwa prevalensi balita gemuk menurut $\mathrm{BB} / \mathrm{TB}$ pada anak usia 0-59 bulan sebesar 11,8\% sedangkan data survey pemantauan status gizi (PSG, 2015) menyatakan bahwa prevalensi balita gemuk menurut $\mathrm{BB} / \mathrm{TB}$ usia $0-59$ bulan sebesar $5,3 \%$. Hasil Riskesdas tahun 2013 juga menggambarkan sebanyak 8 dari 100 anak di 
Indonesia mengalami obesitas. Prevalensi obesitas anak yang dihitung berdasarkan indeks massa tubuh dibandingkan usia (IMT/U) pada kelompok anak usia 5-12 tahun. Prevalensi tertinggi obesitas pada anak usia 5-12 tahun adalah provinsi DKI Jakarta (Depkes, 2013).

Banyak penelitian mengungkapkan bahwa pemberian ASI kepada anak memiliki faktor risiko yang rendah untuk memiliki penyakit kardiovaskular seperti total serum kolesterol (TC) dan kolesterol LDL (LDL-C) (Holmes etc, 2009). Akan tetapi hasil penelitian lain oleh Sabanayagam yang berjudul Obesity: Researchers from National University of Singapore describe findings in obesity in children menyatakan tidak ada keterkaitan antara memberi ASI eksklusif dengan kenaikan berat badan. Oleh karena itu penelitian ini dilakukan untuk mengetahui hubungan antara pemberian ASI ekslusif dengan risiko obesitas pada anak Balita.

\section{METODE}

Metode yang digunakan dalam penelitian ini adalah telaah publikasi berbahasa Indonesia dengan kata kunci "hubungan ASI eksklusif dengan obesitas pada anak Balita", yang dipublikasika secara online dalam kurun waktu sepuluh tahun terakir (tahun 2010-2020). Dari hasil penelusuran ditemukan delapan publikasi dengan teks yang lengkap.

\section{HASIL DAN PEMBAHASAN}

\section{Air Susu Ibu}

ASI (Air Susu Ibu) adalah air susu yang dihasilkan oleh ibu dan mengandung semua zat gizi yang diperlukan oleh bayi untuk kebutuhan pertumbuhan dan perkembangan bayi. Sedangkan ASI eksklusif adalah Bayi hanya diberi ASI saja, tanpa tambahan cairan lain seperti susu formula, air jeruk, madu, air teh, air putih dan tanpa tambahan makanan padat seperti pisang, pepaya, bubur susu, biskuit, bubur nasi dan tim, sampai bayi berusia 6 bulan (Mufdlilah dkk,2017).

ASI eksklusif adalah pemberian ASI tanpa makanan tambahan lain pada bayi beruur
0-6 bulan. Bayi tidak diberikan apa-apa, kecuali makanan yang langsung diproduksi oleh ibu karena bayi memperoleh nutrisi terbaiknya melalui ASI. ASI eksklusif adalah makanan terbaik yang harus diberikan kepada bayi karena didalamnya terkandung hampir semua zat gizi yang dibutuhkan oleh bayi. ASI merupakan makanan bayi yang paling sempurna, mudah dicerna dan disera karena mengandung enzim pencernaan, dapat mencegah terjadinya penyakit infeksi karena mengandung zat penangkal penyakit, praktis dan mudah memberikannya, serta murah dan bersih (Yuliarti,2010).

Saat ini, jumlah ibu yang memberikan ASI eksklusif kepada bayinya sampai berumur 6 bulan masih rendah, yaitu kurang dari $2 \%$ dari jumlah total ibu melahirkan. Hal tersebut lebih disebabkan oleh beberapa alasan, antara lain karena pengetahuan ibu tentang pentingnya ASI masih rendah, tata laksana rumah sakit yang salah, dan banyaknya ibu yang mempunyai pekerjaan di luar rumah.

Menurut Yuliarti(2010) terdapat empat manfaat kolostrum pada ASI yang berguna bagi bayi, antara lain :

a. Mengandung zat kekebalan terutama immunoglobulin $\mathrm{A}(\mathrm{Ig} \mathrm{A})$ untuk melindungi bayi dari berbagai penyakit infeksi, seperti diare.

b. Jumlah kolostrum yang diproduksi bervariasi, tergantung isapan bayi pada hari-hari pertama kelahiran. Walaupun sedikit, namun cukup memenuhi kebutuhan gizi bayi.

c. Mengandung protein dan vitamin A yang tinggi, serta mengandung karbohidrat dan lemak yang rendah sehingga sesuai dengan kebutuhan gizi bayi pada hari-hari pertama kelahiran bayi.

d. Membantu mengeluarkan mekonium, yaitu kotoran bayi yang pertama berwarna hitam kehijauan.

\section{Obesitas pada Anak}

Menurut WHO

obesitas merupakan penumpukan lemak yang berlebihan akibat ketidakseimbangan asupan energi (energy intake) dengan energi yang 
digunakan (energy expenditure) dalam waktu lama. Menurut Solihin (1997) dalam penelitian Ekawati (2013) bahwa berdasarkan patogenesisnya kegemukan dapat dibagi dalam dua golongan yaitu :

a. Regulatory obesity : gangguan primernya berada pada pusat yang mengatur masukan makanan

b. Obesity metabolic : pada kegemukan metabolic terdapat kelainan pada metabolism lemak dan karbohidrat

Menurut Soetjiningsih (1995) dalam penelitian Sarudarma (2011) Anak obesitas memiliki bentuk muka yang tidak proporsional, hidung dan mulut relatif kecil dan memiliki dagu ganda. Terdapat timbunan lamak pada daerah lengan atas, payudara, perut, dan paha. Timbunan lemak ini menyebabkan payudara anak obesitas laki-laki terlihat tumbuh, penis terlihat kecil, dan jari-jari terlihat kecil dan runcing. Pada beberapa bagian tubuh terdapat striae Obesitas pada anak menjadi faktor risiko beberapa penyakit seperti kardiovaskular, diabetes mellitus tipe 2, hipertensi, hiperlipidemia, non alcoholic fatty liver disease (NAFLD), pubertas dini, haid yang tidak teratur dan sindrom ovarium polikistik, steatohepatitis, sleep apnea, asma, gangguan muskuloskeletal, dan masalah psikologi seperti depresi.

Hubungan Pemberian ASI Eksklusif dengan Obesitas pada Anak

Berdasarkan Hasil kajian pustaka dari 8 jurnal yang memenuhi kriteria, terdapat 5 jurnal yang menyatakan bahwa ada hubungan bermakna antara pemberian ASI eksklusif dengan risiko obesitas pada balita. Umumnya balita yang tidak diberi ASI Eksklusif memiliki risiko untuk obesitas. Hasil penelitian Dewi (2014) menunjukkan bahwa lama pemberian ASI dan pola makan berhubungan dengan kejadian obesitas pada anak usia 2-5 tahun $(\mathrm{p}<0,05)$. Lama pemberian ASI secara signifikan dapat menurunkan risiko obesitas sebesar 15\% (OR: 0,855; CI 95\%=0,797 - 0,907; $\mathrm{p}=0,000$ ). Sedangkan pola makan anak dapat meningkatkan risiko terjadinya obesitas sebesar 1,055 kali, artinya semakin banyak jumlah, jenis, dan frekuensi makanan yang dikonsumsi pada anak maka semakin berpeluang untuk terjadi obesitas (OR: 1,055; CI 95\%= 1,004 $1,110 ; p=0,035)$. ASI mengandung hormon dan faktor pertumbuhan (growth faktor) yang sesuai agar petumbuhan badan ideal. Berbeda dengan kandungan susu formula yang memerlukan pengenceran dengan kadar tertentu yang berbeda-beda untuk setiap anak. Jika terlalu cair, dapat menyebabkan bayi kekurangan gizi sehingga pertumbuhannya terhambat. Sebaliknya, jika pengenceran terlalu pekat, dapat memicu kegemukan dan obesitas. Dua kasus ini sering terjadi dalam kehidupan sehari-hari. Bayi yang mendapat ASI pada umumnya lebih ringan/ideal daripada bayi yang mendapat susu formula. Hal ini karena ASI mengandung leptin yang merupakan hormon pengatur nafsu makan/asupan makanan dan metabolism energy (Ariani,2009).

Terdapat 3 jurnal dari 8 jurnal yang menyatakan bahwa tidak ada hubungan antara pemberian ASI eksklusif dengan risiko obesitas pada balita. Dalam penelitian Fitriarni (2012) didapatkan proporsi kegemukan pada anak usia 6-23 bulan adalah 22,6\% dan proporsi ASI eksklusif sebesar 19,9\%. Dari hasil uji chisquare diketahui tidak ada hubungan bermakna antara ASI eksklusif dengan kegemukan, sedangkan hubungan yang bermakna ditemukan pada variable berat lahir, pekerjaan ibu dan pengeluaran keluarga. Hasil penelitian tersebut didukung dengan penelitian Ekawati (2013) dengan penelitian analitik menggunakan desain kasus control. Balita dengan kegemukan umur 6-59 bulan dan sejumlah 215 dengan control balita yang tidak gemuk 6-59 bulan. Hasil analisis multivariat menyatakan bahwa tidak ada hubungan antara riwayat pemberian ASI tidak eksklusif dengan kegemukan ada balita 659 bulan.

Hasil penelitian Satyawati dan Sidiartha (2015) dengan penelitian studi deskriptif analitik dengan pendekatan cross sectional. Data dianalisis menggunakan Chi-square test, risk estimated, dan regresi logistik didapatkan hasil bahwa 16 dari 55 anak yang mendapat ASI lebih dari 1 tahun $(29,1 \%)$ mengalami obesitas. Dua puluh satu dari 60 anak yang mendapat 
Tabel 1. Kajian Pustaka

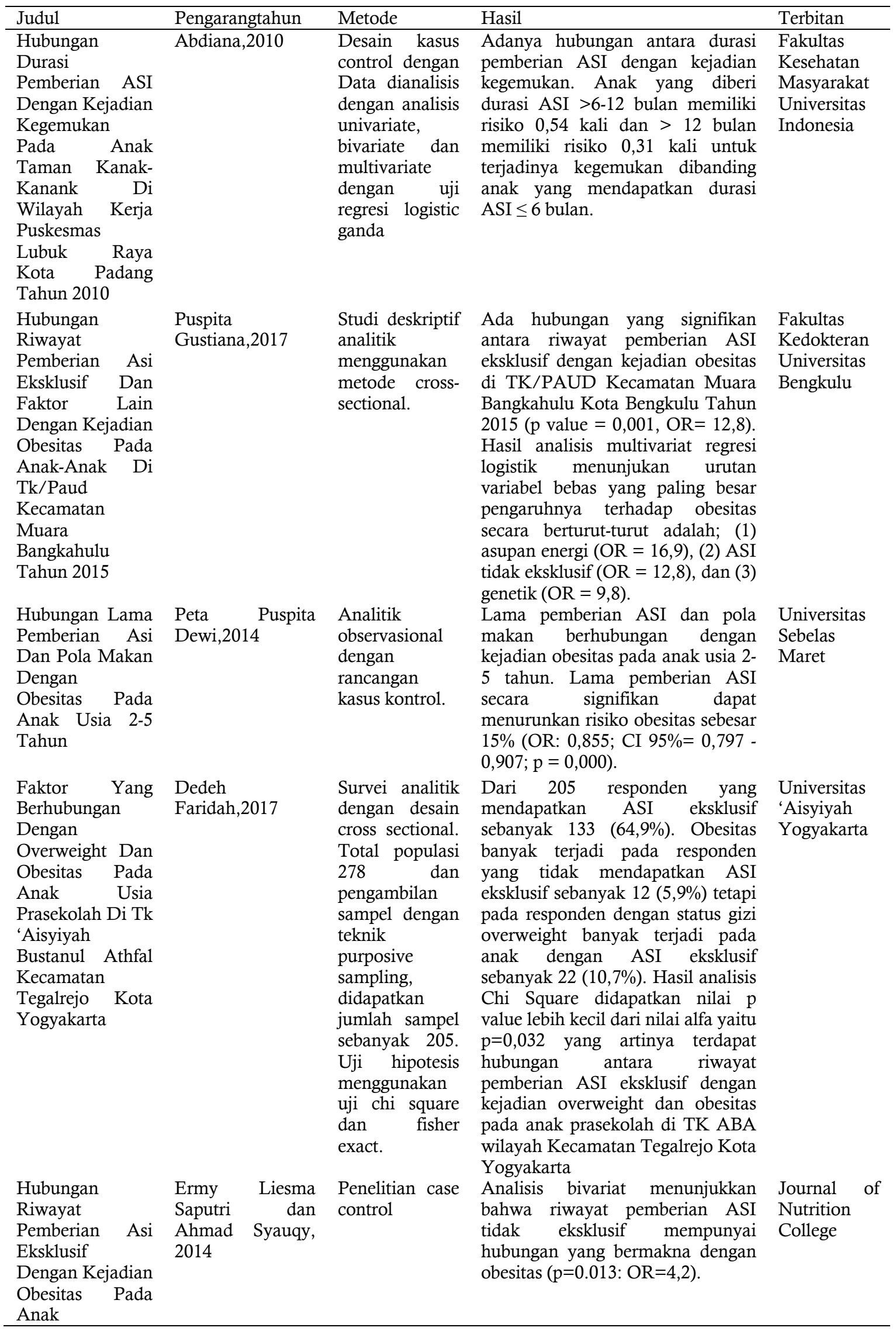


ASI kurang dari atau sama dengan 1 tahun (35\%) mengalami obesitas, dan 6 dari 13 anak yang tidak mendapat ASI sama sekali $(46,2 \%)$ mengalami obesitas. Risiko obesitas lebih tinggi pada anak yang tidak mendapat ASI. Hasil analisis bivariat terhadap riwayat pemberian ASI ditemukan nilai $\mathrm{p}=0,537$, Odd ratio (OR) 0,758, 95\% interval kepercayaan $(0,314 ; 1,829)$. Durasi pemberian ASI didapatkan nilai $p=0,479$. Penelitian ini menemukan riwayat pemberian ASI dan durasi pemberian ASI tidak berhubungan secara signifikan dengan kejadian obesitas pada anak Sekolah Dasar.

\section{PENUTUP}

Berdasarkan hasil penelitian dapat disimpulkan bahwa terdapat hubungan yang signifikan antara pemberian ASI eksklusif dengan obesitas pada balita. Balita yang tidak diberi ASI eksklusif memiliki risiko lebih besar untuk obesitas. Perlunya promosi lebih gencar dilakukan oleh tenaga kesehatan, Puskesmas, dan Dinas Kesehatan untuk melakukan penyuluhan terkait pentingnya ASI eksklusif. ASI eksklusif bukan hanya menurunkan risiko obesitas akan tetapi memberikan pengaruh positif terhadap pertumbuhan dan perkembangan anak.

\section{DAFTAR PUSTAKA}

A Abdiana. 2010. Hubungan Durasi Pemberian Asi Dengan Kejadian Berat Badan Lebih Pada Anak Taman Kanak-Kanak. MKA, 37(1):5157.

Sekar, Ayu Destya., Handayani, Oktia Woro Kasmini. 2016. Diary Teratas (Terapi Anak Obesitas) Dalam Perubahan Perilaku Gizi Siswa Sekolah Dasar.

Connolly, Mary Ellen, Rita Tracewell. 2012. Breastfeeding and Obesity. Bariatric Nursing and Surgical Patient Care, 7(3):132-135

Deplewski, Dianne.2018. BMJ Best Practice Obesity in Children.London : BMJ Publishing Group Ltd. Dewi. 2014. Hubungan Lama Pemberian Asi dan Pola Makan dengan Obesitas pada Anak Usia 2-5 Tahun [tesis]. Surakarta (ID): Universitas Sebelas Maret.
Faridah, Dedeh. 2017. Faktor yang Berhubungan Dengan Overweight dan Obesitas pada Anak Usia Prasekolah di Tk 'Aisyiyah Bustanul Athfal Kecamatan Tegalrejo Kota Yogyakarta [naskah publikasi].Yogyakarta (ID). Universitas 'Aisyiyah Yogyakarta.

Fitriarni. 2012. Hubungan Konsumsi ASI Eksklusif dan Faktor Lainnya dengan Kejadian Kegemukan pada Anak Usia 6-23 bulan di Indonesia tahun 2010 (Analisis Data Riskesdas 2010) [skripsi]. Depok (ID): Universitas Indonesia.

Gustiana,2017. Hubungan Riwayat Pemberian Asi Eksklusif dan Faktor Lain dengan Kejadian Obesitas pada Anak-Anak di Tk/Paud Kecamatan Muara Bangkahulu Tahun 2015 [tesis]. Bengkulu (ID): Universitas Bengkulu.

Holmes, Valerie A, Chris Cardwell, Michelle C McKinley, et al. 2009. Association between breast-feeding and anthropometry and CVD risk faktor status in adolescence and young adulthood: The Young Hearts Project, Northern Ireland. Public Health Nutrition: 13(6), 771-778.

Husnah. 2012. Tatalaksana Obesitas. Jurnal Kedokteran Syiah Kuala, 12(02): 99-104.

Sabanayagam.2009. Obesity; Researchers from National University of Singapore describe findings in obesity in children. Atlanta: NewsRx.

Saputri, Ermy Liesma. 2013. Hubungan Riwayat Pemberian Asi Eksklusif Dengan Kejadian Obesitas Pada Anak Usia 4-5 Tahun [skripsi]. Semarang (ID): Universitas Diponogoro Semarang.

Sartika, Ratu Ayu Dewi. 2011. Faktor Risiko Obesitas Pada Anak 5-15 Tahun di Indonesia. 15(1):37-43.

Satyawati, Ayu Putri, I Gusti Lanang Sidiartha. 2015. Hubungan Riwayat Pemberian Asi Dan Durasi Pemberian Asi Dengan Kejadian Obesitas Pada Anak Sekolah Dasar. E-Jurnal Medika Udayana, 4(9): 1-15.

Sjarif D. Anak gemuk, apakah sehat? Jakarta: Divisi anak dan penyakit metabolic. FKUI: Jakarta, 2004.

Soetjiningsih. 1995. Tumbuh Kembang Anak, Jakarta: ECG

Yuliarti, Nurheti. 2010. Keajaiban ASI Makanan Terbaik Untuk Kesehatan, Kecerdasan, Dan Kelincahan Si Kecil.Yogyakarta: Andi Offset. 